\title{
On the Loftiness of Relational Identity
}

\author{
Ephraim Meir \\ (Bar-Ilan University, Israel)
}

One of the problems of today's life lies in the neglect of interconnectedness. Another problem arises when the autonomy of the individual person is endangered by the presence of an all-absorbing totality. The combination between separability and connection to the larger society permits us to think together the unique value of each person as well as the social dimension in the human being. Marcia Pally has developed a theologically based ontology in which relationality and separatedness are not contradictory. ${ }^{1}$ Her ontology of separability-amidsituatedness has political and economic relevance and keeps the balance between autonomy and relatedness. ${ }^{2}$ In my contribution to Staszek's Festschrift, I focus upon the problem of distinction without relation. The greater well-being of all is violated if too much accent is put on separatedness or autonomy that overlooks the responsibility towards others.

The Renaissance discovered the individual, who cannot be wrapped in a whole or absorbed in a general category. During the age of Enlightenment, Kant urged his reading public to free themselves from mental immaturity and to think for themselves. These are important developments that rescue the individual from totalizing movements. Today, more than ever, we pay attention to the individual

1 M. Pally, Commonwealth and Covenant. Economics, Politics, and Theologies of Relationality, Grands Rapids, MI: William B. Eerdmans, 2016.

2 Sallie King kindly refers me to the Karmapa, Ogyen Trinley Dorje, Interconnected: Embracing Life in our Global Society, Somerville, MA: Wisdom Publications, 2017, who also keeps the balance between the two. I wholeheartedly thank Prof. King for her pertinent remarks on a previous version of this article. 
person and her potentiality. With the growing globalization, the postmodern human being becomes less and less rooted in traditional societies. She has the possibility to realize herself in a variety of ways and in a multiplicity of relationships. We construct ourselves. We are mobile, change our countries, personal status, work places, lifestyles, ideas and worldviews. We shape ourselves in a free way. We criticize metanarratives and feel flexible in our choices. More and more, personal narratives replace traditional metanarratives.

The accent upon the individual and her rights is certainly an achievement of our times, in which the individual self-realization has become the task of the day. It is also a healthy remedy against totalitarianism. However, focus on the individual goes often on the account of interrelatedness and of belonging to others. The emancipation of the individual frequently goes hand in hand with a loss of stability and a sense of loneliness and isolation. ${ }^{3}$ The $I$ is no longer a mere instance of a collectivity. It has become highly individualized. Yet, is identity imaginable without alterity? Can one be oneself without the other?

\section{I-it and I-you}

In his I and Thou, Buber developed a dialogical-relational way of thinking, in which not the self and its interests, but the orientation to a you is central. $\mathrm{He}$

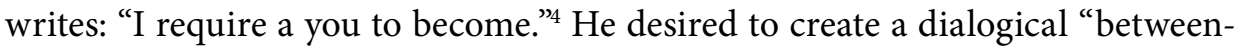
man" (Zwischenmensch); through a you, a person becomes I. Buber considered the inter-human to be a primal category of human reality. He pointed to the sphere of the "between" (zwischen) as a humanizing factor in human society.

\footnotetext{
What is said about the individual who constructs his identity in dialogue with others, pertains also to collectives. Not only the individual may neglect his belonging to others. Entire groups perceive others as unwanted outsiders. They claim that they are only accountable for their own group and exclude deviant members of their own group who are suspected of inserting foreign ideas and behaviors. Confronted with insecurity, people nostalgically long to be part of closed groups that discriminate people inside and outside and even refuse to recognize others as human beings. The health of a collective I can be measured by its relationship to other collective I's. See E. Meir, "The Contributions of Modern Thought to a Psychoanalytic Phenomenology of Groups," Psychoanalysis and Contemporary Thought, 19,4 (1996), pp. 563-578.

4 M.Buber, I and Thou, transl. Walter Kaufman, New York: Charles Scriber's Sons, 1970, 62 (Ibid., Ich und Du. Um ein Nachwort erweiterte Neuausgabe, Heidelberg: Lambert Schneider, 1958, p. 15: Ich werde am Du).
} 
He distinguished between I-you and I-it. The I in itself is inexistent: it is I-you or I-it. ${ }^{5}$ In I-it, the I borders on another it; I-you is without borders. I-you does not have or experience something: I-you stands in relation. ${ }^{6}$ The I-it, on the contrary, creates a world of space and time, experience and description, of measure and comparison. This is a world of analysis, causality, classification and consciousness. The I-you attitude is holistic, non-partial and unmediated. Encountering a you, the I is entirely "present" (gegenwärtig) and makes a you present.

Buber's dialogical philosophy describes the "spirit" as happening between I and you: it is the possibility to say "you," the ability to relate: "Spirit is not in the I but between I and you. It is not like the blood that circulates in you but like the air in which you breathe. Man lives in the spirit when he is able to respond to his you. He is able to do that when he enters into this relation with his whole being. It is solely by virtue of his power to relate that man is able to live in the spirit." 9

Buber's philosophy is one of in-between-ness. Putting the intersubjective encounter at the center of his philosophy, he deems that one is really oneself in relation with the non-self. In the outward movement from the I to the other, one senses the humanity of a human being. The I-you is the deeper I, beyond experiencing and using. It is a dialogical I, which makes the human being human:"[...] without It a human being cannot live. But whoever lives only with that is not human."

Describing the evolution of a human being, Buber states that our first and primal way of living is a life in relationship to others: "In the beginning is the relation." ${ }^{11} \mathrm{He}$ argues that, in the development of a child, individuation comes only after a symbiotic phase in life, in which relatedness is vital. The child's longing for relation is primary and precedes its autonomy. In his transformational writing, Buber wants his readers to leave their ego (Eigenwesen) that only differentiates them from others, in order to become a person (eine Person), a real

\footnotetext{
I and Thou, p. 54.

I and Thou, pp. 55-56, 61.

For the relevance of Buber's category of presence for the interreligious encounter, see E. Meir, "The Relevance of Buber's Category of 'Presence' for the Interreligious Dialogue and the Construction of a Dialogical Theology," in Archivio di filosofia LXXXVI, 2 (2018), pp. 237-246.

8 I and Thou, p. 100.

9 I and Thou, p. 89.

10 I and Thou, p. 85.

11 I and Thou, p. 69 (Ich und Du, p. 20: Im Anfang ist die Beziehung).
} 
human being related to others. ${ }^{12}$ A human being becomes real in relationships with others: "All actual life is encounter." ${ }^{13}$ Moreover, Buber distinguishes between the singular one, who flees from the world, and the unique one, who takes upon himself responsibility for the world and becomes engaged in public life. ${ }^{14}$ Dissimilar to Kierkegaard's individual, who is cut off from the world, Buber's individual is connected to others as fellow human beings. In his book The Question of the Single One Buber protests against any form of totalitarianism and pleads for personal responsibility.

In The Problem of Man, which Buber published first in Hebrew in 1943, he introduces the sphere of the "between" as a fundamental category of human reality. ${ }^{15}$ The "between" is absent in the isolated being as well as in an all-encompassing totality. It is, rather, present in the meeting that is not reducible to one's interiority or to an all-absorbing exteriority. In dialogue, an individual and a community become real. Buber criticizes both individualism and collectivism. The former isolates the human being, who becomes a monad. The latter disregards the individual and glorifies the anonymous masses, without acknowledging individual responsibility. Buber opposed the totalitarianism of his time and saved the individual and her responsibility, but he also objected to the alienation of the individual human being, who is unable to communicate and to relate to a you.

\section{From self to soul}

Similar to Buber, Rosenzweig approaches the I as I-in-relation. In his Star of Redemption, he develops the thought that the command "You shall love" makes a "self" (Selbst) into a "soul" (Seele).With the divine command, the "mute self" becomes a "speaking soul." ${ }^{16}$ For Rosenzweig, the I is a substance beyond its being

\footnotetext{
I and Thou, p. 113.

I and Thou, p. 62 (Ich und Du, p. 15: Alles wirkliche Leben ist Begegnung).

14 See M. Buber, “The Question of the Single One," in Will Herberg (ed.), The Writings of Martin Buber, New York: Meridian Books, 1958, pp. 63-88. The book Die Frage an den Einzelnen first appeared in 1936 (Berlin, Schocken Verlag).

15 M. Buber, Das Problem des Menschen, Heidelberg: Lambert Schneider, 1948.

16 F. Rosenzweig, The Star of Redemption, transl. Barbara E. Galli, Madison, Wisc.: The University of Wisconsin Press, 2005, p. 213 (Ibid., p. Der Stern der Erlösung, Frankfurt a.M.: Suhrkamp, 1988, 221: Mündigwerden des stummen Selbst zur redenden Seele).
} 
called, but the soul "springs from the Self of man." ${ }^{17}$ Consequently, the natural, mute self and the speaking soul are separated, but not without connection. In response to the non-I, the I becomes "here I am," it is not anymore closed in itself. This metamorphosis is made possible by the appeal to the human being, which is palpable in the command, "You shall love." This imperative interrupts the natural course of things. Death is the end of finite beings, who - however - may experience that "love is strong as death."18 Something overflows death. In this an extraordinary experience, the solitary person of the past becomes a speaking soul in the present, related to the world and creating a future in the midst of a community. In the miracle of love, a person receives a soul and becomes animated, with language becoming alive in her. The human being is ordered to enliven other human beings. Love makes life lively and animates the inanimate. In the pure present of the love command, man feels alive, addressed and personal. He escapes the totality of the self and is rescued from enclosure in the prison of himself. The beloved one, who becomes a lover, vanquishes death.

Rosenzweig's insight of the self that becomes a soul received its expression in his personal life. Instead of deadening science, he preferred to become engaged in community life. The living encounter with human beings became more important than a science that is not connected to people. In his Lehrhaus, he was linked to every Jew, without excluding anyone. He also shaped his own Jewish identity in permanent dialogue with his Christian friends. In this way, he exemplified what a dialogical life is about.

\section{I “without identity"}

Also in Levinas's provocative philosophy of the other, the I is summoned by the other. Levinas explicitly recognizes the inspiration and heritage of Rosenzweig in this point. ${ }^{19}$ In his Otherwise than Being, the I is chosen before any beginning;

17 Star, p. 184 (Stern, p. 190: entspringt aus dem Selbst des Menschen).

18 Star, p. 169. In reference to the Song of Songs 8:6.

19 Myriam Bienenstock has observed that Levinas does not have a theory of recognition, but rather of "substitution," without relation. M. Bienenstock, "Zur Dialogphilosophie von Emmanuel Levinas: auf den Spuren von Franz Rosenzweig," in Helmut Schneider and Dirk Stederoth (eds.), Dialektik und Dialog. Wolfdietrich Schmied-Kowarzik zum 80. Geburtstag, Kassel: Kassel University Press, 2019, pp. 47-53, more specially p. 52. Dissimilar to Paul Ricoeur and Jean-Luc Marion, she deems that Levinas's thoughts can be better explained through Rosenzweig's view- 
it is foreign to itself, "here am I" (me voici). For Levinas, "uniqueness is without identity" and "the other is in me." ${ }^{20}$ Criticizing the ego's spontaneity, he states that the I is called into question, exposed to the other. The subject is not a being that reflects the Being in an Heideggerian manner, it is rather "subjected" to the other, singled out by the other to be for the other. ${ }^{21}$ Rather than constituting the other, the other constitutes the I: "The other is in me and in the midst of my very identification. The ipseity has become at odds with itself in its return to itself. The self-accusation of remorse gnaws away at the closed and firm core of consciousness, opening it, fissioning it." 22 I am "through the other and for the other"; the I is "without fatherland," even "without identity," it is a restless me, wholly turned to the other. ${ }^{23}$ The I's vocation is to provide for the needs of the other and to be attentive to her rights, without interest. Levinas uses dramatic words, and characterizes the I as "persecuted," "obsessed," "exposed," "traumatized," "hostage," "elected" and "accused." 24 With this particular language, he wants to describe the I as burdened by the needs of the other. The I cannot escape the other, as the prophet Jonah cannot escape the people of Ninive. ${ }^{25}$ Ipseity is not identity which is the return to itself, it is rather "my substitution for another." ${ }^{26}$ In Levinas's philosophy of transcendence, the I has the other in herself, her identity is broken: it is the elected and unique one-for-the other.

\section{Common ground}

With all the differences between them, the Jewish philosophers quoted above all describe, analyze and promote an identity that allows for a life in brother- and

point rather than through Levinas's discussion with Heidegger. Op. cit., pp. 52-53.

20 E. Levinas, Otherwise than Being or Beyond the Essence, transl. A. Lingis, The Hague: Nijhoff, 1981, pp. 57, 125.

21 Otherwise than Being, p. 125.

22 Otherwise than Being, pp. 124-125.

23 Otherwise than Being, pp. 103, 114.

24 Playing on the double meaning of the French word "accuser", Levinas deems that the I that manifests and presents itself, is at the same time accused.

25 Levinas, Carnets de captivité, suivi de Écrits sur la captivité et Notes philosophiques diverses, Rodolphe Calin and Catherine Chalier (eds.), Paris : Bernard Grasset/IMEC, 2009, p. 79; Ibid., Existence and Existents, trans. Alphonso Lingis, Dordrecht:Kluwer, 1995, p. 67.

Otherwise than Being, p. 125. 
sisterhood, in freedom and justice. Such an identity is never self-oriented. Of course, it cannot be proved that the I is connected to the other. One cannot convince one of this truth. But one may "testify" to this elevated reality, as Levinas highlights. ${ }^{27}$ In an accomplished life, the I becomes I through the non-I.

Staszek is well acquainted with the philosophies described above and has written about them in a sensitive way. He is himself a creative Jewish dialogical thinker. Also in other cultures, one finds refined thoughts on interconnectedness. In the following, I offer some Buddhist thoughts that discuss the theme of interconnectedness and that come close to Buber's dialogical thinking. I focus on the writings of the Vietnamese monk Thich Nhat Hanh, who has made an enormous effort in order to make his Buddhist wisdom known to and practiced in the West.

\section{Being as inter-being}

Thich Nhat Hanh is also called Thây, the Vietnamese word for "teacher." Thây is a Vietnamese monk, born in 1926. He is a Zen Buddhist, a man of peace and social justice, a poet and one of the foremost leaders of the Engaged Buddhism movement. ${ }^{28}$ This wise, spiritual man founded with others the School of Youth for Social Service, in which young people became engaged in schools and health clinics and rebuilt bombed villages in Vietnam. He called for peace between the warring parties in Vietnam. In 1966 he started his oversea tours in the US and Europe. When Vietnam refused his return, he received asylum in France. He lived in Plum Village, the Buddhist monastery and practice center near Bordeaux. The village is called that way because of hundreds of plum trees, which the community members tend to. He cared for the Vietnamese boatpeople fleeing from Vietnam by organizing ships to rescue them and healed Vietnamese and American suffering. He is a healer for many people, providing appropriate remedies for pain and wounds, a dialogical person in his own way.

Thây wants us to return to our true self, to be awake by being mindful. In his view, there is no separate self, because of the interconnection of all with all. ${ }^{29}$

27 Otherwise than Being, p. 147.

28 For more on engaged Buddhism: Sallie B. King, Socially Engaged Buddhism. Dimensions of Asian Spirituality, Honolulu: University of Hawai'i Press, 2009.

29 Thich Nhat Hanh, The Miracle of Mindfulness. The Classic Guide, London: Rider,2008, p. 42. 
Following the famous Buddhist logic of non-duality, I can say that Thây is in me, since I am studying him. "One is all, all is one." ${ }^{30}$ Our own life and that of the universe are one. ${ }^{31}$ Thây uses the word "one-ness," 32 but he is suspicious about concepts and wants the reader to experience directly without any concept: "Don't rush from the concept of 'two' to the concept of 'one'." ${ }^{33}$ One has to leave the prison of concepts and to experience the world directly.

Thây contests the subject-object scheme: "True understanding happens when we dismantle the barrier between the object of understanding and the subject of understanding." ${ }^{34} \mathrm{He}$ brings the story of the grain of salt that wants to know how salty ocean water is. The only way to know that is to jump in the water. ${ }^{35}$ What may be experienced through our body and our senses is our connection with the world. This radical interconnectedness is linked to the "wisdom of nondiscrimination," in which there is no giver and no receiver. If there is still a giver and receiver, the gift is not perfect. ${ }^{36}$

In the Buddhist way of life, being is inter-being. The English term "inter-being" was coined by Thây in order to free us from our feeling of isolation and bring us again into contact with the world through our bodies. "We inter-are with one another and with all life." ${ }^{37}$ Separateness is a problem: "When we can free ourselves from the idea of separateness, we have compassion, we have understanding, and we have the energy we need to help." ${ }^{38}$ Here, of course, Thây is not reasoning like Buber, for whom separatedness and interconnectedness cannot be

\footnotetext{
$30 \quad$ Ibid., p. 45.

Ibid., p. 48.

Ibid., p. 42.

Thich Nhat Hanh, The Sun My Heart, London: Rider, 1992, p. 11. Thanks to Sallie King who referred me to this saying, which reminds me of the title of the book of the Hindu theologian Anantanand Rambachan: A Hindu Theology of Liberation: Not-Two Is Not One (Albany: Suny Press, 2015). Rambachan's point is that the Advaita tradition sees in every human being an embodiment of the infinite, but the concept of not-two (advaita) does not lead to a negative attitude towards the finite. (Ibid., p. 65) The world is brahman but brahman is not the world. (Ibid., p. 66) Not-two is not one.

34 Thich Nhat Hanh, Reconciliation. Healing the Inner Child, Berkeley CA: Parallax Press, 2010, p. 58.

35 Ibid., pp. 57-58.

36 Ibid., p. 58.

37 Thich Nhat Hanh, The Art of Living, London: Rider, 2017, p. 13.

Ibid., p. 20.
} 
divorced. ${ }^{39}$ But also for Thây, oneness is not a totalizing totality which completely dissolves the individual.

In his unitive, non-dual view, Thây shows how all is re-manifested: the rain is a re-manifestation of the cloud..$^{40}$ In this sense, a cloud does not die..$^{41}$ Neither do we die..$^{42}$ Death is transformation. ${ }^{43}$ It took millions of years to give rise to two eyes, legs, feet and hands. ${ }^{44}$ This was possible because of the interrelatedness of all, in which nothing is lost. Therefore, "[i]nput and output are always taking place." ${ }^{35}$ When the petals of the plum blossom fall, this is not the end of the plum tree. Thây sees himself as a wave in the ocean. He sees himself in all the other waves and all the other waves are in him. The manifestation or disappearance of the wave, he concludes, does not lessen the presence of the ocean. ${ }^{46}$ It is clear that, in this Buddhist view, the boundaries between the I and the other(s) become fluid and blurred. Using another simile, Thây writes that a flower is made up of non-flower elements, of earth, sun and other elements. A flower is a cloud. How can Thây say that? Without a cloud, there is no rain and without rain a flower cannot be. Therefore, a flower is a cloud. Being for Thây is inter-being. ${ }^{47}$ All is interconnected. Thây is the prisoners who read his books. ${ }^{48} \mathrm{~A}$ parent is his child, a grandfather his grandchildren; ${ }^{49}$ the I is made of non-I elements. ${ }^{50}$

Close to Buber's focus on the purity of intention of I-you, Thich Nhat Hanh writes: "Mindful observation is based on the principle of 'non-duality': our feeling is not separate from us or caused merely by something outside us: our feeling is us, and for the moment we are that feeling." ${ }^{.1}$ However, Buber's initial focus

39 M. Buber, "Urdistanz und Beziehung," Studia Philosophica - Jahrbuch der Schweizerischen Philosophischen Gesellschaft, Separatum Vol. X, Basel: Verlag für Recht und Gesellschaft, 1950, pp. 7-19.

40 The Art of Living, p. 42.

41 Ibid., p. 44.

42 Ibid., pp. 43-44.

43 Ibid., p. 48.

$44 \quad$ Ibid., p. 56.

45 Ibid., p. 57.

46 Ibid., p. 79.

47 Thich Nhat Hanh, No Mud, No Lotus, Berkeley CA: Parallax Press, 2014, pp. 12-13.

48 The Art of Living, p. 66.

49 Ibid., p. 67.

50 Ibid., p. 85 .

51 Thich Nhat Hanh, Peace Is Every Step. The Path of Mindfulness in Everyday Life, London: Rider, 1995, p. 51. 
on the intentionality of the I in I and Thou is gradually replaced by his close attention to what happens between persons. Thây concentrates on what happens in one's interiority and what leads to suffering and isolation: mindfulness is like a mother, taking care of her crying baby. ${ }^{52} \mathrm{He}$ further distinguishes between relative or conventional truth and ultimate truth: "In everyday language, we say 'you' and 'I' and 'we' and 'they' because these designations are useful. They identify who or what we are talking about, but it is important to realize they are only conventional designations. ${ }^{53}$ In the ultimate truth, there is no owner and no boss. ${ }^{54}$ Thây remembers once seeing a cartoon of Descartes in front of a horse. Descartes declares "I think, therefore I am." The horse behind him wonders: " Therefore you are what?" 55 Buber's philosophy differs from Thây's unitive thinking and values more the separatedness of a person, whose humanity lies nevertheless in her interconnectedness. For both thinkers, separation is secondary, relation - primordial.

Thây and Buber both know the redeeming force of being present. Thây writes that loving is "recognizing the presence of the other with your love." It is being there for the beloved one. ${ }^{56}$ And one's presence is "the most precious gift you can give him or her." ${ }^{57}$ Similar to Buber, Thây puts the emphasis on the present moment. ${ }^{58}$ Living in the present moment is touching life deeply. ${ }^{59}$ Living the present mindfully makes one aware of the miracles in life, of the miracle of an orange, for instance. ${ }^{60}$ By living in the present, one releases worries, fear or anger of the past and the future.

Thây's Buddhist point is that by being present, one lessens the suffering in oneself and in others. Moreover, in true love, there is no separation or discrimination. One is linked to others like fingers of the same hand. ${ }^{61}$ Thây and Buber

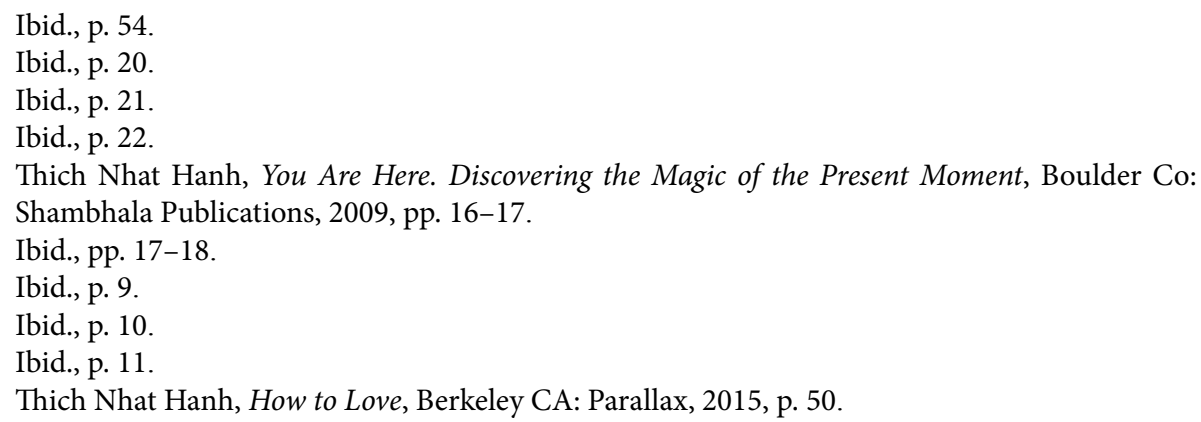


have very different lifestyles and ways of looking at life, but with their transformative meditations and poetic language both intend to make the other real. ${ }^{62}$

\section{Conclusion}

Each person is unique and nevertheless we are all interconnected. The Buberian in-between-ness, Rosenzweig's self that becomes a soul under the command "You shall love" and Levinas's I as "substitution" all go in the direction of an I, that is called to relate to others. Thich Nhat Hanh's Buddhism too is about the loftiness of relatedness. For him, all is interdependent. Cooperation and reciprocity avoid the suffering of greed, destructive competition and self-absorption. I safely conclude that great minds in several cultures converge in their view on the loftiness of interrelatedness, which is badly needed in a world of extreme individualism that neglects relationships.

\section{Bibliography}

Bienenstock M., "Zur Dialogphilosophie von Emmanuel Levinas: auf den Spuren von Franz Rosenzweig," in Helmut Schneider and Dirk Stederoth (eds.), Dialektik und Dialog. Wolfdietrich Schmied-Kowarzik zum 80. Geburtstag, Kassel: Kassel University Press, 2019, 47-53.

Buber M., Die Frage an den Einzelnen, Berlin, Schocken Verlag, 1936.

Buber M., Das Problem des Menschen, Heidelberg: Lambert Schneider, 1948.

Buber M., "Urdistanz und Beziehung," Studia Philosophica - Jahrbuch der Schweizerischen Philosophischen Gesellschaft, Separatum Vol. X, Basel: Verlag für Recht und Gesellschaft, 1950, 7-19.

Buber M., Ich und Du. Um ein Nachwort erweiterte Neuausgabe, Heidelberg: Lambert Schneider, 1958.

Buber M., "The Question of the Single One," in Will Herberg (ed.), The Writings of Martin Buber, New York: Meridian Books, 1958, 63-88.

62 Ibid., p. 122. 
Buber M., I and Thou, transl. Walter Kaufman, New York: Charles Scriber's Sons, 1970.

King S.B., Socially Engaged Buddhism. Dimensions of Asian Spirituality, Honolulu: University of Hawai'i Press, 2009.

Levinas E., Otherwise than Being or Beyond the Essence, transl. A. Lingis, The Hague: Nijhoff, 1981.

Levinas E., Existence and Existents, trans. Alphonso Lingis, Dordrecht: Kluwer, 1995.

Levinas E., Carnets de captivité, suivi de Écrits sur la captivité et Notes philosophiques diverses, Rodolphe Calin and Catherine Chalier (eds.), Paris : Bernard Grasset/IMEC, 2009.

Meir E., "The Contributions of Modern Thought to a Psychoanalytic Phenomenology of Groups," Psychoanalysis and Contemporary Thought, 19,4 (1996), 563-58.

Meir E., "The Relevance of Buber's Category of 'Presence' for the Interreligious Dialogue and the Construction of a Dialogical Theology," in Archivio di filosofia LXXXVI, 2 (2018), 237-246.

Ogyen Trinley Dorje, Interconnected: Embracing Life in our Global Society, Somerville, MA: Wisdom Publications, 2017.

Pally M., Commonwealth and Covenant. Economics, Politics, and Theologies of Relationality, Grands Rapids, MI: William B. Eerdmans, 2016.

Rambachan A.: A Hindu Theology of Liberation: Not-Two Is Not One, Albany: Suny Press, 2015.

Rosenzweig F., Der Stern der Erlösung, Frankfurt a.M.: Suhrkamp, 1988.

Rosenzweig F., The Star of Redemption, transl. Barbara E. Galli, Madison, Wisc.: The University of Wisconsin Press, 2005.

Thich Nhat Hanh, The Sun My Heart, London: Rider, 1992.

Thich Nhat Hanh, Peace Is Every Step. The Path of Mindfulness in Everyday Life, London: Rider, 1995.

Thich Nhat Hanh, The Miracle of Mindfulness. The Classic Guide, London: Rider, 2008.

Thich Nhat Hanh, You Are Here. Discovering the Magic of the Present Moment, Boulder Co: Shambhala Publications, 2009.

Thich Nhat Hanh, Reconciliation. Healing the Inner Child, Berkeley CA: Parallax Press, 2010. 
Thich Nhat Hanh, No Mud, No Lotus, Berkeley CA: Parallax Press, 2014.

Thich Nhat Hanh, How to Love, Berkeley CA: Parallax, 2015.

Thich Nhat Hanh, The Art of Living, London: Rider, 2017.

\section{Summary}

The article deals with the uniqueness and interconnectedness of human beings. It is argued that the Jewish philosophers Buber, Rosenzweig and Levinas as well as the Buddhist thinker Thich Nhat Hanh emphasize the relatedness of the subject. This is viewed as a welcome correction in a world of extreme individualism.

Key words: individual, interconnectedness, identity

\section{Streszczenie}

\section{O wzniosłości tożsamości relacyjnej}

Artykuł dotyczy problemu wyjątkowości ludzi i ich wzajemnych powiązań. Żydowscy filozofie, tacy jak Bauber, Rosenzewig i Levinas, oraz buddyjski myśliciel Thich Nhat Hanh wyraźnie podkreślają znaczenie więzi między ludźmi. Postrzegamy to jako cenną korektę w świecie skrajnego indywidualizmu.

Słowa kluczowe: indywiduum, wzajemne powiązanie, tożsamość 